\title{
A SONEGAÇÃO HISTÓRICA DE DIREITOS ANIMAIS E A CONSTRUÇÃO DO ANIMAL COMO NÃO-SUJEITO: NOTAS A PARTIR DO PARADIGMA DA HUMANIDADE
}

\author{
LA RETENCIÓN HISTÓRICA DE LOS DERECHOS ANIMALES Y LA \\ CONSTRUCCIÓN DE LO ANIMAL CÓMO NO-SUJETO: NOTAS DESDE EL \\ PARADIGMA DE LA HUMANIDAD
}

\author{
${ }^{1}$ Bianca Pazzini
}

\section{RESUMO}

Sendo ainda flagrante a falta de prescrição de quaisquer direitos efetivos para os animais, e subsistindo o especismo como principal "modo de existir humano", apresenta-se como problemática a necessidade de apurar quais os fundamentos filosóficos, históricos e jurídicos de tal discriminação, a fim de aventar as possibilidades de desconstrução de tais concepções. Partindo-se da perspectiva histórica, objetiva-se detalhar um dos mais relevantes fundamentos do especismo, o nominado paradigma da humanidade por ter se mostrado, ao longo dos séculos, como o mais contundente meio de justificativa da subalternização dos animais. Quanto à pesquisa científica, utilizar-se-á da literatura como aporte lúdico para a discussão teórica, à medida que é de fundamental importância ao permitir um diálogo mais rico e criativo na inserção de elementos estéticos em assuntos teóricos. Adotar-se-á como metodologia a pesquisa bibliográfica, valendo-se de procedimentos analíticos e históricoestruturais. Justifica-se a pesquisa pela contundente necessidade de superação das barreiras especistas que impossibilitam a declaração dos animais como indivíduos sujeitos de direitos.

Palavras-chave: Direitos animais, Paradigma da humanidade, Retrospectiva histórica, Especismo

\footnotetext{
${ }^{1}$ Mestranda em Direito e Justiça Social na Universidade Federal do Rio Grande - FURG, Rio Grande - RS (Brasil). Professora da Universidade Federal do Rio Grande - FURG, Rio Grande - RS (Brasil).

E-mail: biancapazzini@gmail.com
} 


\section{RESUMEN}

Sigue siendo flagrante la falta de prescripción de cualquier derecho para los animales, y siendo subsistente el especismo como lo principal modo de la existencia humana, se presenta como problemática la necesidad de determinar los fundamentos filosóficos, históricos y jurídicos de tal discriminación, con el fin de señalar las posibilidades de deconstrucción de tales concepciones. A partir de la perspectiva histórica, el objetivo es detallar uno de los fundamentos más relevantes del especismo, el nominado paradigma de la humanidade por haber estado, a lo largo de los siglos, como el medio más contundente de justificación de la subordinación de los animales. En lo relativo a la investigación científica, se utilizará la literatura como contribución lúdica a la discusión teórica, ya que es de fundamental importancia para permitir un diálogo más rico y creativo em la inserción de elementos estéticos en los asuntos teóricos. Se adoptó como metodología la investigación bibliográfica, haciendo uso de los procedimientos analíticos e histórico-estructurales. Se justifica la investigación por la necesidad contundente de superar las barreras especistas que hacen imposible la declaración de los animales como individuos sujetos de los derechos.

Palabras-claves: Derechos animales, Paradigma de la humanidad, Retrospectiva histórica, Especismo 
No intentamos volver a dialogar con el hermano Lobo, sino que le reventamos la cabeza de un escopetazo porque estaba em nuestro dominio y nos molestaba, y también hicimos lo mismo con el hermano índio, negro, judio, etc ${ }^{1}$ (ZAFFARONI, 2013, p. 126).

\section{INTRODUÇÃO}

Ante a flagrante perpetuação da discriminação entre seres humanos e animais, permanecem estes subalternizados e excluídos das searas de proteção jurídica - por sua condição de não-sujeitos. Assim, apresenta-se como problemática a necessidade de apurar quais são os fundamentos filosóficos, históricos e jurídicos de tal discriminação, a fim de que sejam aventadas as possibilidades de desconstrução de tais concepções.

Parte-se de uma perspectiva de retrospecto, dado que as construções teóricas do presente são sempre fruto das conexões feitas pelas gerações anteriores. O ser humano nasce, cresce e se desenvolve sempre em observância a tudo o que foi edificado pela humanidade que lhe precedeu. Sendo fruto de seu meio, a pessoa é moldada pela sociedade paulatinamente erigida em seu entorno, num continuиm temporal permanente.

Logo, ao iniciar uma investigação científica, o sujeito-pesquisador vê-se na árdua tarefa de, antes de apresentar um prognóstico para o futuro de seu objeto de pesquisa, prostrar-se em postura retroativa para encontrar no passado os fundamentos de sua experiência contemporânea. Sem isso, a construção epistemológica não evolui, gerando uma eterna "redescoberta da roda".

Compreendendo-se tais aspectos no trabalho ora proposto, objetiva-se fazer uma análise historiográfica da relação entre seres humanos e animais desde uma perspectiva jurídicofilosófica (epistemologicamente colonizada pelo Ocidente), que permita um olhar tão acurado quanto possível sobre os acontecimentos do passado.

Nesse sentido, sabe-se que a história da relação entre animais ${ }^{2}$ e seres humanos se confunde com a própria história da humanidade. Antes de as sociedades arcaicas de caçadores-

\footnotetext{
1 Tradução livre: "Não tentamos dialogar com o irmão Lobo, mas arrebentamos sua cabeça com uma espingarda, porque ele estava em nosso domínio e nos incomodava, e também fizemos o mesmo com o irmão índio, negro, judeu etc".

2 Utilizar-se-á a expressão "animais" como diferenciadora e contraposta à expressão "seres humanos". Muito embora seja absoluto consenso que os seres humanos participam da animalidade comum a todos os seres

sencientes, entende-se que a dicotomia "animais humanos/ animais não-humanos" é menos apropriada, por reforçar o ser humano como critério de classificação para a nomenclatura. Dizer que algo "é” ou "não é” tal coisa mantêm o foco nessa coisa. Assim, com vistas à superação do paradigma antropocêntrico, entende-se como importante retirar o humano da centralidade da classificação. Não se nomeia algo a partir da sua "não-essência". Além disso, o uso do termo "animal” (embora também objetável) já é de convenção linguística, o que gera uma comunicação mais simples e eficiente.
} 
coletores se espalharem pela Terra, a vida humana já era perpassada por uma relação de dominação e uso de animais.

Assim, partindo-se dessa perspectiva histórica, impõe-se detalhar um dos mais relevantes fundamentos do especismo ${ }^{3}$, que aqui se nomina como "paradigma da humanidade" - definido como autoproclamação arbitrária do humano como "ser excelso", superior aos demais animais (que são tratados como meros instrumentos ou coisas). Sem rechaçar a existência de outros paradigmas especistas, procura-se focar nesse que se mostrou como o mais contundente na subalternização dos animais.

Para além das referências históricas, filosóficas e jurídicas, utilizar-se-á da literatura como aporte lúdico para a discussão teórica. A despeito de tal abordagem não ser praticada no âmbito das pesquisas jusanimalistas ${ }^{4}$, entende-se que é de fundamental importância à medida que permite um diálogo mais rico e criativo, inserindo elementos estéticos em assuntos que costumam ser eminentemente técnicos. Afinal de contas, se é possível pensar na existência e na consagração (hipotética) de direitos para o psiquiatra Simão Bacamarte ${ }^{5}$ ou para o finado Brás $\mathrm{Cubas}^{6}$, porque não se pode fazer o mesmo em relação ao fiel canino Quincas Borba ${ }^{7}$ ? E em momento posterior, na chamada "vida real", porque não fazê-lo em favor de um cachorro abandonado que precisa de cuidados ou de uma vaca confinada em uma indústria leiteira?

Ademais, se é possível pensar (n)a vida de alguém, parece lógico também sentir alguma comoção para com essa existência, externando simpatia em relação a esse ser. John M. Coetzee, pela voz de Elisabeth Costello na obra literária “A Vida dos Animais", contribui em muito para a questão, ao trazer o conceito "imaginação simpatizante" para com os animais, que pode construir bases sólidas para uma nova concepção de alteridade não especista.

\footnotetext{
3 Utilizar-se-á, por opção estética, o termo "especismo" em detrimento de "especiesismo". Especismo trata-se de "Expressão cunhada por Richard Ryder [...] para designar o preconceito exercido pelos seres humanos em face dos animais com a finalidade de subjugá-los e explorálos pelo simples fato de eles não pertencerem à nossa espécie e, por isso, não serem dignos de consideração ética ou moral" (PAZZINI, 2014, p. 136). De acordo com a professora Sônia Felipe trata-se da "Discriminação de animais não-humanos, praticada pelos seres humanos, rebaixando o estatuto daqueles, em função de não terem nascido na espécie humana e de terem características diferentes em sua configuração biológica, ainda que sejam sujeitos de experiências similares às dos seres humanos, por exemplo, dor e sofrimento" (FELIPE, 2009, p. 210).

4 Jusanimalista (SILVA, 2013a, p. 182; SILVA, 2013b, p. 245, 259-260, 262; SILVA, 2014, p. 52) é uma nomenclatura específica apta a designar o jurista especialista na disciplina jurídica de direitos animais. É um termo de aplicação muito recente, mas que se adota por sua adequação prática e especificidade técnica.

5 Personagem principal do conto "O Alienista" (1882), de Machado de Assis, que se instala na cidade de Itaguaí, fundando um hospício chamado Casa Verde (ASSIS, 2007, p. 38-81).

6 Narrador-personagem da obra "Memórias Póstumas de Brás Cubas" (1881) (ASSIS, 1999).

7 Personagem-cão do romance homônimo de Machado de Assis (1891). Esse também é o nome do tutor do canino, o filósofo Quincas Borba, falecido, que deixa sua fortuna para o amigo Rubião, com a condição de que ele preste o compromisso de cuidar do referido cachorro (ASSIS, 1994).
} 
As contribuições literárias estão no mundo das ideias tanto quanto a filosofia ou o direito, o que as torna passíveis de incorporação na investigação científica, e com o benefício de terem sido desenvolvidas a partir de um senso ou prisma estético, o que geralmente não se vê presente nas ciências humanas e sociais.

Sendo assim, adotar-se-á como metodologia a pesquisa bibliográfica, valendo-se de procedimentos analíticos e histórico-estruturais, sendo adotado como método de confecção o monográfico.

Por fim, entende-se que a presente pesquisa justifica-se pela contundente necessidade de superação das barreiras especistas que impedem a declaração dos animais como indivíduos sujeitos de direitos.

\section{OS SERES HUMANOS, OS ANIMAIS E O MEIO AMBIENTE: FUNDAMENTOS PRELIMINARES PARA A SUPERAÇÃO DO ESPECISMO}

Estipula-se que há cerca de dois milhões de anos tenham surgido os "primeiros antecessores diretos" da espécie hominídea (Homo erectus), que se caracterizavam por serem nômades e por viverem em pequenos grupos familiares, não obstante suas atividades pudessem já ter um caráter efetivamente predatório, com extinção de diversas espécies animais (LOURENÇO, 2008, p. 43).

Fato é que, desde o princípio, "o homem transforma o mundo que o rodeia. Transformação discreta e como que carregada de culpabilidade num primeiro tempo, que depressa se tornará brutal, maciça e dominadora" (OST, 1995, p. 33).

A História começa, contudo, em torno do desenvolvimento da agricultura, há cerca de dez mil anos atrás. Ali o Homo sapiens muda contundentemente sua organização social, lançando as bases para a consagração das noções de propriedade e de Estado.

Segundo Morin e Kern (2003, p. 15):

\footnotetext{
A História nasce há talvez dez mil anos na Mesopotâmia, há quatro mil anos no Egito, há dois mil e quinhentos anos no vale do Indo e no vale do Haung Po na China. Numa formidável metamorfose sociológica, as pequenas sociedades sem agricultura, sem Estado, sem cidade, sem exército, dão lugar a centros urbanos, reinos e impérios de várias dezenas de milhares, depois centenas de milhares e milhões de súditos, com agricultura, cidades, Estado, divisão do trabalho, classes sociais, guerra, escravidão, mais tarde grandes religiões e grandes civilizações.
} 
É nesse contexto que se torna mais estreita e senhorial a relação com muitos animais. Primeiro, a domesticação do cão - há cerca de doze mil anos atrás. Posteriormente a da ovelha, que em seguida já passa a ser explorada economicamente (NACONECY, 2006, p. 105; LOURENÇO, 2008, p. 44). Estima-se que nos últimos seis mil anos "o homem ${ }^{8}$ cria animais com o único propósito de comê-los ou vestir sua pele" (NACONECY, 2006, p. 105) e que há três ou quatro mil anos tenha domesticado praticamente todas as plantas e animais tidos incorporados à cultura humana.

Considerando isso, interessa analisar, então, os paradigmas dessa relação especista cujo início coincide com o surgimento do que Enrique Dussel (2012, p. 11) chama de "sistemamundo", que continua "se globalizando até chegar ao último rincão da Terra, excluindo, paradoxalmente, a maioria da humanidade" e - conforme é possível perceber de maneira flagrantemente absurda - a totalidade dos animais. Para tal autor, o ápice dessa globalização excludente é também uma grande crise, que deve ser tratada a partir de uma ética de afirmação da vida em favor de uma total libertação.

Ost corrobora tal pensamento, afirmando que:

Esta crise é simultaneamente a crise do vínculo e a crise do limite: uma crise de paradigma, sem dúvida. Crise do vínculo: já não conseguimos discernir o que nos liga ao animal, ao que tem vida, à natureza; crise do limite: já não conseguimos discernir o que deles nos distingue (OST, 1995, p. 9).

A crise, é sobretudo, epistemológica. Decorre do "resultado da fé incondicional na perfeição humana que nega a complexidade do mundo e de suas relações" (SILVA, 2013a, p. 161). Mais do que rearranjar conhecimentos, valores e vínculos, mostra-se indispensável reconstruir o próprio conhecimento da espécie humana, para que se consiga migrar para uma nova forma de pensamento livre de barreiras antropocêntricas e especistas. Imperioso, assim, conhecer o passado a fim de compreender o que levou a essa forma de pensamento excludente, pois, de acordo com o famoso aforisma de Jorge Santanaya, "quem não conhece o passado está condenado a repetí-lo".

Desse modo, voltando à questão temporal que se refere ao início da diferenciação discriminatória - entre seres humanos e animais, tem-se:

\footnotetext{
8 Quer-se dizer aqui que o ser humano de sexo masculino, branco, patriarca, proprietário de bens e declarada heterossexualidade, que, por ser o detentor do poder econômico e político, sempre liderou as atrocidades perpetradas contra os animais. Idealmente se utilizará a expressão "ser humano" em detrimento da expressão "homem" considerando que essa última não contempla toda a espécie e tem caráter sexista - não obstante ainda sejam tidas como sinônimos.
} 
For four Thousand years, a thick and impenetrable legal wall has separated all human from all nonhuman animals. On one side, even the most trivial interests of a single species - ours - are jealousy guarded. We have assigned ourselves, alone among the million animal species, the status of 'legal persons'. On the other side of the wall lies the legal refuse of an entire kingdom, not just chimpanzees and bonobos but also gorillas, orangutans, and monkeys, dogs, elephants, and dolphins. They are 'legal things'. Their most basic and fundamental interests - their pains, their lives, their freedoms - are intentionally ignored, often maliciously trampled, are routinely abused (WISE, 2000, p. 4) 9 .

Mas como começa essa diferenciação? Como se constitui o "ser humano por excelência" - de sexo masculino, branco, patriarca, proprietário e de declarada heterossexualidade - um déspota perante os demais animais? Antes de adentrar a tal sucessão histórica, convém sinalar que, por uma questão de especialidade científica, ficam de fora da presente investigação as questões atinentes à relação do ser humano com o restante da natureza que o permeia.

Ocorre que, ao contrário do que afirma o senso comum científico ambientalista- animalista, as questões que envolvem os direitos animais e os direitos da natureza (ou direito ambiental) não podem mais serem tratadas com correspondência teórica, dada a diversidade de objetos. Não obstante se saiba que os animais façam parte dessa totalidade complexa ${ }^{10}$ (e quase transcendente) chamada de Terra-pátria (MORIN; KERN, 2003), Gaia (LOVELOCK, 2006) ou Pachamama (ZAFFARONI, 2013), entende-se que em nada se confundem com ela.

Os animais, assim como os seres humanos, pressupõem um tratamento filosófico e jurídico individualizado. Por consequência, os direitos animais, assim como os direitos humanos, têm em foco a individualidade de cada um dos seres que representam, sobrelevando seus respectivos valores intrínsecos. Em outras palavras, a disciplina jurídica "direitos animais" defende cada animal na mesma medida que a disciplina "direitos humanos" defende cada um dos humanos, pelo que se entende (por mais absurdo que pareça para quem ainda conserva uma visão antropocêntrica, ou, no mínimo antrópica ${ }^{11}$ ) que os direitos dos animais se aproximam mais dos direitos humanos do que do direito ambiental.

\footnotetext{
9 Tradução livre: "Há quatro mil anos, uma espessa e impenetrável parede legal tem separado todos humanos de todos os animais não-humanos. Por um lado, até mesmo os interesses mais triviais de uma única espécie - a nossa - são cuidadosamente guardados . Temos atribuído a nós mesmos, dentre as milhões de espécies de animais, o estatuto de "sujeitos de direitos". Do outro lado dessa parede encontra-se a negação legal de um reino inteiro, não apenas chimpanzés e bonobos, mas também gorilas, orangotangos, macacos, cães, elefantes e golfinhos. Eles são “objetos de direito". Os seus mais básicos e fundamentais interesses - seus sofrimentos, suas vidas, suas liberdades - são intencionalmente ignorados, muitas vezes maliciosamente pisoteados, e rotineiramente abusados" (WISE, 2000, p. 4).

10 Para Eugênio Raul Zaffaroni (2013), grande jurista argentino, os direitos animais seriam enquadrados dentro da deep ecology, com o que se discorda, dada a existência de um objeto de estudo específico e diverso.

11 O princípio antrópico, de acordo com José Roque Junges, "aponta para o pressuposto de que o ser humano ocupa um lugar central em qualquer discurso ético, pois somente as ações do ser humano podem ser fruto de decisões livres e intencionais e apenas ele que propõe questões éticas" (JUNGES, 2004, p. 111).
} 
Por outra perspectiva, percebe-se que a natureza, ao ser tutelada pelo direito ambiental, agrega em sua demanda valores ecológicos e holísticos em prol da preservação do todo. Vêse cada indivíduo (de qualquer espécie) como uma simples "nano peça" de um todo amplo e complexo. Para o direito ambiental, não interessa uma vida, mas o equilíbrio vital que mantém a Terra em condições para a própria manutenção. Por menos que se queira pensar dessa forma, a ideia de natureza vista como valor intrínseco sempre pode ser falsa, porque ela é naturalmente um bem de interesse da humanidade. Sempre será de interesse "salvar" a Terra apenas porque sua existência é premissa fundamental de mantimento da vida humana - o que necessariamente lhe dá um valor instrumental, por mais que o discurso tenha sido satisfatoriamente construído no sentido de atribuir-lhe valor intrínseco - na migração do conceito de "natureza-objeto" para o de "natureza-sujeito" e para o de "natureza-projeto" (OST, 1995).

Ainda que a visão seja voltada para uma "ecologia profunda"12, "ecocêntrica" ou "biocêntrica" em detrimento de uma "ecologia superficial"13 ou "ambientalista" (FERRY, 2009, p. 31; ZAFFARONI, 2013, p. 69-70), não muda o fato de ser vantajoso manter Gaia viva. Sabe-se que a Terra deve ser salva do esgotamento porque implica necessariamente em preservação da espécie humana. Logo, por mais importante que seja discutí-lo, o direito ambiental pode não fugir das amarras do antropocentrismo, porque tem como pré-condição o fato de ter um valor mediato, e não imediato; é uma finalidade necessariamente humana, e não um fim em si mesmo. Em sendo assim, salvar a fauna não vai significar salvar animais, mas apenas manter o equilíbrio das condições planetárias/ambientais para subsistência da vida humana.

Por outro lado, não quer dizer que a fauna, como valor próprio (e por consequência o direito ambiental), não interesse aos direitos animais. Muito pelo contrário. Quem quer salvar a individualidade também o quer quanto à coletividade, como parece óbvio. Ou quem quer o bem de cada um dos humanos (o que também se quer efetivamente) não quer o bem da humanidade?

\footnotetext{
12 A ecologia ambientalista mantém claramente o humano como titular de direitos, não obstante possa reconhecer obrigações de respeito à natureza.

13 A ecologia profunda (deep ecology) reconhece a natureza como sujeito de direitos, e tira a centralidade do ser humano. Contudo, mantém o caráter holístico e sistêmico próprio da essência ecológica. Aldo Leopold (1887-

1948) é o precursor dessa teoria, e afirma que existe uma base ética comum a todos os seres vivos na Terra, não podendo o homem perder o "espírito" comunitário decorrente desse fato. Tem raízes filosóficas no utilitarismo de Bentham, que por sua vez também foi utilizado como base teórica para as primeiras obras animalistas (ZAFFARONI, 2013, p. 71) pelo engenho de Henry Salt (que em 1892 publica Animal Rights) e de Peter Singer (que em 1975 publica Animal Liberation).
} 
O que se critica é que, para a ecologia e para o direito ambiental, os animais são meras "peças" de uma grande engrenagem, que podem ser substituídas sem problemas, desde que mantendo a "máquina" (Planeta Terra) funcionando. Se um determinado grupo de peixes (fundamental para mantimento do equilíbrio de um determinado meio aquático) for substituído por outro de igual função, está cumprido o desiderato ecológico.

Vai nesse sentido a ponderação da personagem de John M. Coetzee, Elisabeth Costello, que em "A Vida dos Animais", reflete acerca da "condição ecológica":

Os animais não acreditam em ecologia. [...]

Nós, os gerentes da ecologia [...], nós gerentes entendemos a dança maior, portanto podemos decidir quantas trutas podem ser pescadas ou quantos jaguares podem ser enjaulados sem afetar a estabilidade da dança. O único organismo sobre o qual não pretendemos ter esse direito de vida e morte é o homem. Por quê? Porque o homem é diferente. $\mathrm{O}$ homem entende a dança de um jeito que os outros dançarinos não são capazes de entender. O Homem é um ser intelectual (COETZEE, 2002, p. 65).

Os direitos animais, de maneira fortemente diversa, percebem em cada vida um valor verdadeiramente intrínseco (sem qualquer caráter instrumental para o ser humano). O valor "vida" (aliado a outros valores, tais como dignidade e liberdade) não deverá ser sopesado em relação à interesses alheios ao do ser vivente, que tem importância em si mesmo.

É dessa maneira que os direitos animais se dissociam do direito ambiental, aproximando-se de uma lógica muito mais parecida com os direitos humanos. Seja como for, ambas disciplinas têm em comum o fato de "descentralizar" e "dessacralizar" o ser humano como "ser excelso" do universo. Ademais, entende-se o direito ambiental como o "local de nascimento" dos direitos animais, não obstante, se defenda tal separação pela natural diferença de foco e pela necessidade de afirmação dos direitos animais como disciplina jurídica autônoma.

Por derradeiro, defende-se que, do ponto de vista dogmático, os direitos animais constituem disciplina jurídica autônoma por possuírem objeto específico, legislação própria e procedimento diverso do direito ambiental.

Superada tal questão, convém adentrar ao cerne do presente artigo. Para tanto, optou-se por não fazer uma mera historiografia pura e simples, mas uma análise focada no surgimento de um dos maiores paradigmas - ainda não superados - de afirmação e consolidação (social, filosófica e jurídica) da dominação humana sobre os animais ao longo da história desse já referido "sistema-mundo", a saber, o valor "humanidade".

Uma mera sucessão histórica pode ter fins didáticos bem importantes no sentido de reconhecer como se deu o desenvolvimento do especismo ao longo do tempo, mas a proposta 
que ora se apresenta tem uma finalidade diversa. Ao detectar quais são os grandes paradigmas em torno do tema, mostra-se mais fácil pensar argumentos para superá-lo. Apontar o tema de maneira linear - e cartesiana - só teria fins informacionais, sem qualquer caráter propositivo.

Entende-se que a evolução histórica demonstrou a existência de três grandes fundamentos ao especismo, quais sejam: (a) o paradigma da humanidade; (b) o paradigma da transcendência; e (c) o paradigma da razão. De modo geral, esses foram os mais relevantes modelos de diferenciação entre o ser humano e o animal ao longo do tempo - muito embora não ocorrendo de maneira isolada e sucessiva, mas geralmente de maneira simultânea e não linear.

Resumidamente, o "paradigma da humanidade" - objeto do presente estudo - revela a autoproclamação do humano como "ser excelso" pelo simples fato de ser o que é. O homem é o único ser que é um fim em si mesmo, superior aos animais (que são meros instrumentos ou coisas).

O "paradigma da transcendência", por sua vez, demonstra que Deus teria eleito o homem como ser superior da criação (pelo menos no que diz às religiões ocidentais especialmente o cristianismo. Para estas, o ser humano está mais perto de Deus do que os outros seres vivos).

Por último, o "paradigma da razão" é o embasamento científico do paradigma da humanidade. Nele, o homem se autonomeia "a espécie das espécies", mas justificando tal eleição embasado em características especiais suas - intelecto mais desenvolvido, articulação racional - que lhe dão status superior em virtudes dessas faculdades. É uma versão atualizada, moderna e cientificista do paradigma da humanidade - que vê os animais como máquinas.

Tais paradigmas aqui elencados não são numerus clausus. Mostram-se como os mais contundentes, mas certamente não os únicos ${ }^{14}$. Para a presente pesquisa, conforme aponta o título, optou-se por estudar apenas o "paradigma da humanidade", com a finalidade de aprofundar seus fundamentos históricos, filosóficos e jurídicos, dando a atenção que o tema merece e abrindo espaço de pesquisa para posterior análise dos demais paradigmas.

\footnotetext{
14 A propriedade, por exemplo, poderia ser apontada como outro parâmetro histórico de dominação dos seres humanos sobre os animais, pois os interesses econômicos sempre foram um dos maiores empecilhos na superação do especismo. Entretanto, entende-se que tal aspecto perpassa, de alguma forma, todos os demais, podendo apresentar-se inclusive como fundamento implícito.
} 


\title{
2 O PARADIGMA DA HUMANIDADE COMO PRINCIPAL MEIO DE CONSTRUÇÃO DO ANIMAL COMO NÃO-SUJEITO
}

Ao longo do tempo, o termo "humanidade" foi utilizado várias vezes como critério de exclusão, não apenas em relação aos animais, mas inclusive em detrimento de humanos. Escravos, servos, hereges, súditos, judeus, negros, pobres, indígenas, mulheres e homossexuais já foram excluídos desse conceito, a fim de possibilitar a hegemonia e o domínio de alguns poucos "seres humanos por excelência" sobre os demais seres vivos.

A construção (artificial) de uma "humanidade" seletiva serviu como critério de afirmação de fronteiras entre aquilo que seria escolhido como "humano" ou não. Tal critério, entretanto, não seria biológico, porque nem os animais e nem todos os seres humanos compunham esse universo, como acima citado.

Então, considerando a problemática ora apresentada, objetiva-se, nesta seção, a análise do que se detectou como "paradigma da humanidade" como critério de exclusão dos animais da seara de consideração moral pela simples elevação dos humanos a um status superior de tratamento jurídico e social. Tal fato revelou-se como uma das formas mais contundentes de aparição do especismo, ao lado das manifestações religiosas e da valoração da razão como um fim em si mesmo.

Nessa perspectiva, tem-se:

\begin{abstract}
A idéia (sic) de superioridade humana está fortemente impressa na mentalidade da civilização ocidental, que tradicionalmente tem se limitado à autopromoção da excepcionalidade da nossa espécie. Agindo como cabotina, ela festeja euforicamente sua própria posição no Universo - no centro ou acima dele - legitimando-se a si mesma, narcisicamente e no seu próprio interesse. A partir disso, os argumentos humanistas vêm sendo usados para justificar a escravização e a coisificação dos animais (NACONECY, 2006, p. 66).
\end{abstract}

Atribui-se aos primeiros pensadores e filósofos (ocidentais) a ideia de afirmação do ser humano em posição de destaque perante o restante das espécies. Uma das primeiras reflexões nesse sentido aparece em "Antígona", de Sófocles (442 a.C.), na qual há a ideia de que "o homem é uma exceção dentro do conjunto da natureza" (LOURENÇO, 2008, p. 45): "De tantas maravilhas/ mais maravilhoso de todas é o homem" (SÓFOCLES, 2013, p. 27).

Ademais, tal tragédia grega traz, em outra passagem, que “[...] nada supera/ o homem que, por natureza, é dotado de saber" (SÓFOCLES, 2013, p. 51), o que lhe daria, portanto, a 
arbitrariedade de decidir a sorte de tudo e todos. Tal fato é reforçado pelo papel que Creonte, rei de Tebas, exerce: ao ter o poder de decidir quais súditos (não necessariamente considerados pessoas) vivem e quais morrem, se coloca em uma posição de elevação simbólica em relação ao restante de natureza, ocupando a posição intermediária entre animais e deuses (e talvez até entre humanos e deuses). Nesse tom é a fala de Corifeu: "Mas eis que vem o rei desta terra,/ Creonte Menécio, novo chefe,/ enviado por deuses para novos sucessos" (SÓFOCLES, 2013, p. 17).

No que se refere ao restante do legado grego ${ }^{15}$ quanto à construção da concepção de humanidade, afora as questões que envolvem o pensamento mítico, predominante na época, tem-se que coube aos primeiros filósofos gregos (pré-socráticos) (séc. VI a.C.) erigir "uma nova mentalidade, que passa a substituir as antigas construções mitológicas pela aventura intelectual, expressa através de investigações científicas e especulações fillosóficas" (GRANDES FILÓSOFOS, 2005, p. 5; PRÉ-SOCRÁTICOS, 2005, p.5).

O "paradigma da humanidade" como ferramenta para instauração e mantimento do especismo é trazido dentro do pensamento pré-socrático pela via da Escola Itálica (ou Italiana), na qual Alcmeon de Crotona (560-500 a.C., contemporâneo de Pitágoras), ao distinguir pensamento de percepção, "[...] afirmou que a diferença baseia-se no fato de somente ao homem é dado possuir a verdadeira compreensão, enquanto que às outras criaturas é possível apenas perceber, porém não compreender ou pensar" (LOURENÇO, 2008, p. 55).

De maneira oposta, Pitágoras de Samos (580/78-497/6 a.C.) reconheceu (pela primeira vez na história do Ocidente) um dito "parentesco" de todos os seres humanos com todos os seres vivos, aduzindo que o mundo foi dado igualmente à todas espécies (FELIPE, 2009, p. 4). Segundo ele, "o homem e todo o ser vivo estão enraizados num mundo que, longe de ser o apanágio de alguns, é dado a todos”, igualmente (PITÁGORAS apud FELIPE, 2007). Para ele, "Que horror é engordar um corpo com outro corpo, viver da morte de outros seres vivos" (PITÁGORAS apud NACONECY, 2006, p. 226). Outrossim, “As motivações de Pitágoras fundamentavam-se numa ética cívica: abster-se de carne tornava os homens menos predispostos à violência, e o que fosse incapaz de sacrificar uma vida animal menos ainda atentaria contra um seu semelhante" (DIAS, 2015, p. 87).

15 O legado grego é vastíssimo, e pode ser dividido em várias fases, dentre as quais destacam-se: fase pré-socrática (ou cosmológica), fase socrática, fase sistemática (ou aristotélica) e fase helenística (pós-aristotélica ou greco- romana), para reduzir apenas aos períodos didaticamente apontáveis (CHAUÍ, 2001, p. 34). 
Já para Demócrito de Abdera (460-370 a.C.), “A boa natureza dos animais é a força do corpo; a dos homens, a excelência do caráter" (DEMÓCRITO, 2005, p. 276). Tal pensamento redunda em uma distinção ambígua entre seres humanos e animais: se por um lado reforça a barreira da desigualdade, por outro consagra que não necessariamente os valores dos animais, por serem diferentes dos humanos, devem ser inferiorizados, mas valorizados em sua alteridade. O grande problema dessa postura é que gera, ainda que de maneira implícita e incipiente, uma possibilidade de hierarquização subordinadora dos animais, dado que o caráter ou a consciência (e até a alma, sob outro enfoque) vão ser sempre sobrelevados em detrimento do "mero corpo".

Diógenes de Apolônia (490-428 a.C.), tendo como ponto de partida que o ar é o princípio originário de sua teoria, iguala seres humanos em alguma medida, pois ambos vivem do ar que respiram, ar esse que configuraria uma espécie de alma e inteligência, cuja falta gera o perecimento de ambas espécies (LOURENÇO, 2008, p. 57).

Protágoras de Abdera (490-421 a.C.), apesar de contemporâneo de Diógenes (présocrático, como se viu), é um dos primeiros filósofos da fase socrática, e um dos principais sofistas. Ele foi o responsável pela construção da ideia de "homem-medida", afirmando que "o homem é a medida e todas as coisas, das que são como são e das que não são como não são" (PROTÁGORAS apud LOURENÇO, 2008, p. 60). Ocorre que tal concepção "é perturbadora não só porque não reconhece valor intrínseco aos demais seres vivos, como também instala a discussão acerca dos limites objetivos do que vem a ser humano ou não" (LOURENÇO, 2008, p. 60), o que pode levar a abusos não apenas em detrimento dos animais, mas inclusive em relação aos próprios seres humanos subalternizados, por várias vezes tidos como "não homens" ou "não humanos".

Não obstante os sofistas, como ressaltado, possam ser classificados como socráticos, nunca tiveram a aprovação de Sócrates ${ }^{16}$ (470-399 a.C.), que não os considerava verdadeiros filósofos à medida que, segundo ele, "não tinham amor pela sabedoria nem respeito pela verdade, defendendo qualquer idéia (sic), se isso fosse vantajoso" (CHAUÍ, 2001, p. 37).

De qualquer forma, a fase socrática da filosofia (refletida na realidade jurídico-social da sociedade ocidental) caracteriza-se, em linhas gerais, pelo mantimento do lugar do ser humano como superior aos animais. Tal concepção é exteriorizada pela máxima "homem-medida" de Protágoras, corroborada pelo pensamento antropocêntrico de Sócrates (e posteriormente mantida por seu discípulo Platão), que entendia que os animais tinham o propósito de servir à raça humana. 
A posterior fase da filosofia, nominada de aristotélica ou sistemática ${ }^{17}$ resultou em um grande marco na consolidação do especismo. Aristóteles (384-322 a.C.) ${ }^{18}$ foi um dos grandes responsáveis pela consagração do paradigma da humanidade em detrimento dos direitos animais, pois vislumbrava a existência de uma hierarquia natural e finalística entre os seres humanos e os demais seres vivos (plantas e animais) e os objetos inanimados:

[...] as plantas existem para os animais como os animais para o homem. Dos animais, os que podem ser domesticados destinam-se ao uso diário e à alimentação do homem, e dentre os selvagens, a maior parte pelo menos, senão todos, lhe fornece alimentos e outros recursos, como vestuários e uma porção de objetos de utilidade; e, pois, a natureza nada faz em vão e sem um objetivo, é claro que ela deve ter feito isso para o benefício da espécie humana" (ARISTÓTELES, 2011, p. 32).

Para o filósofo grego, existia uma "grande cadeia dos seres" (scala naturae), dentro da qual cada ser tinha um lugar (pré-determinado e hierarquizado) (GORDILHO, 2008, p. 20), dado que "tudo na natureza foi criado para servir a um propósito específico, a uma 'causa final""19 (LOURENÇO, 2008, p. 66).

Aristóteles não negava, porém, que os seres humanos partilham de natureza animal. Além disso, não via uma diferença abissal entre uns e outros. Entendia que a animalidade era inerente à espécie humana (SINGER, 2013, p. 274-5): "É evidente, pois, que a cidade faz parte das coisas da natureza, que o homem é naturalmente um animal político, destinado a viver em sociedade" (ARISTÓTELES, 2011, p. 21). No entanto, tal semelhança não era suficiente para a igualdade, pois o "homem" (do sexo masculino, grego e livre - representando a significação de humanitas) possuía as capacidades contemplativa e racional, que o elevava a um status superior - diminuindo, por consequência, os demais a status inferior.

\footnotetext{
16 Sócrates, apesar de sua importância para a filosofia (é considerado seu patrono), nunca deixou nada escrito. Tudo o que se sabe de seus pensamentos é por transmissão de, especialmente, dois de seus maiores discípulos: Platão (428/427-348/347 a.C) e Xenofonte (430-355 a.C.). 17 É a fase da filosofia "do final do século V e todo o século IV a.C., quando a Filosofia investiga as questões humanas, isto é, a ética, a política e as técnicas” (CHAUÍ, 2001, p. 34).

18 "Rejeitando o mundo transcendente das idéias (sic) pensado por Platão, seu mestre, Aristóteles elaborou um sistema filosófico abrangente, no qual a ciência tem um papel fundamental" (GRANDES FILÓSOFOS, 2005, p.

23). Sobre uma questão mais especificamente voltada ao tratamento que dispensava aos animais, tem-se a notícia que "realizava vivissecções (operações feitas em animais vivos) e dissecações (secção e individualização dos elementos anatômicos de um organismo morto)" (LEVAI; DARÓ, 2008, p. 43).
} 
Defendia, então, distinções "naturais" entre humanos e animais - este existia para servir àquele -, mas também entre os próprios humanos: se alguns existiam para ser escravos, outros existiam para escravizar ${ }^{20}$ (SINGER, 2013, p. 274-5):

É importante destacar que nessa concepção não só os animais, mas também as mulheres, os escravos e os estrangeiros eram considerados imperfeitos e destinados ao benefício do cidadão grego, enquanto a caça e a guerra eram vistas como formas naturais de conquista e domesticação de animais selvagens e de escravos que, destinados pela natureza a obedecer, às vezes se recusavam a fazê-lo (GORDILHO,

2008, p. 21).

Esse entendimento de que os seres estão escalonados de maneira hierarquizada, instrumental e finalística dá origem ao que ficou conhecido como "Antropocentrismo Teleológico".

Isso não significa, contudo, que Aristóteles pregasse a crueldade para com os níveis mais baixos da escala. Segundo Sônia Felipe, para o referido filósofo, não faz sentido maltratar animais "não porque os animais sofram ou sejam conscientes da dor, mas por serem propriedade (patrimônio) do homem livre. Tudo o que se faz ao animal (propriedade de um homem), que o possa estragar, ferir ou destruir, implica dano ao patrimônio desse" (FELIPE, 2009, p. 6).

Tal posicionamento repisa um entendimento do animal enquanto instrumento ou objeto, e não como um fim em si mesmo (inferior ao ser humano, portanto), reforçando a construção do chamado paradigma humanista.

Em momento histórico posterior, com o início da fase helenística (pós-aristotélica ou greco-romana), tem-se uma continuidade na investigação das questões pensadas pelos filósofos anteriores, especialmente Sócrates, Platão e Aristóteles. Dentre as correntes filosóficas principais desse período, o estoicismo ${ }^{21}$ destacou-se, mostrando-se como relevante na construção do pensamento filosófico, especialmente do que diz à possibilidade de repensar a relação dos seres humanos com os animais, muito embora reforçando outros dogmas especistas pré-existentes.

\footnotetext{
19 “[...] o boi serve de escravo aos pobres" (ARISTÓTELES, 2011, p. 20).

20 “Alguns seres, ao nascer, se veem destinados a obedecer; outros, a mandar. E formam, uns e outros, numerosas espécies. A autoridade é tanto mais alta quanto mais perfeitos são os que a ela se submetem. A que rege o homem, por exemplo, é superior àquela que rege o animal; porque a obra realizada por criatura mais perfeita tem maior perfeição" (ARISTÓTELES, 2011, p. 25).

21 O estoicismo é uma escola filosófica helenística fundada por Zenão de Cítio (333-263 a.C.) e posteriormente compilada por Crísipo (280-208 a.C.)
} 
O estoicismo reforça o paradigma da humanidade à medida que corrobora com a tese de que os animais não têm qualquer valor intrínseco, sendo "simples instrumentos em benefício dos homens" (GORDILHO, 2008, p. 21). Por outro lado, refuta a ideia aristotélica de "escravo natural”, e, conforme ressalta Edna Cardozo Dias (2000, p. 28), “[...] encontramos nos estóicos (sic) a idéia (sic) de que o direito natural é comum a homens e animais. [...] Os seres vivos participam da ratio universal", sem uma sobrelevação especial ser humano em relação ao restante dos seres vivos.

Em suma, o legado grego caracteriza-se pelo distanciamento do ser humano em relação ao mundo natural que o rodeia. A consagração do "homem-medida" acabou por se revelar como uma histórica e definitiva consagração do especismo, pois consolidou um status superior dos seres humanos em relação aos animais.

Posteriormente, com o advento do imponente Império Romano - que vai das origens de Roma (provavelmente séc. VIII a.C.) à morte de Justiniano (565 d.C.), integralmente construído pela guerra e pela violência "precisou devotar muito de energia e recursos às forças militares que defendiam e ampliavam seu vasto território. Essas condições não davam margem a que se acalentassem sentimentos de simpatia pelos fracos" (SINGER, 2013, p. 276). Nesse contexto, humanos e não humanos eram vítimas de um sistema eminentemente excludente, que subalternizava e via as vidas desses subalternos como mero entretenimento.

Os conhecidos jogos romanos eram a representação do ora retratado. Gerações e gerações de mulheres e homens romanos assistiam a atrozes combates entre homens, entre homens e animais ou entre animais, que com o passar do tempo ia ganhando mais traços de crueldade para manter o interesse dos espectadores.

\begin{abstract}
O simples combate tornou-se, por fim, insípido, e todo o tipo de atrocidade era concebido para despertar o interesse que diminuía. Certa feita, um urso e um touro, acorrentados juntos, rolaram nas areias, num combate feroz; outra vez, criminosos vestidos com peles de feras selvagens foram lançados aos touros, que eram atiçados com ferros em brasa ou com dardos dotados de pontas em chamas. Quatrocentos ursos foram mortos num único dia nos tempos de Calígula. [...] Com Nero, quatrocentos tigres lutaram com touros e elefantes. Em um único dia, na inauguração do Coliseu por Tito, quinhentos animais foram mortos. Com Trajano, os jogos chegaram a durar 123 dias consecutivos. Leões, tigres, elefantes, rinocerontes, hipopótamos, girafas, touros, cervos, até crocodilos e serpentes eram utilizados para dar um toque de novidade ao espetáculo. Também não faltava nenhuma forma de sofrimento humano. [...] Dez mil homens lutaram nos jogos de Trajano. Nero iluminava seus jardins, à noite, com cristãos, a cujas túnicas ateavam fogo. Com Dominiciano, um exército de frágeis anões foi obrigado a combater (LECKY, 1869, p. 280-2 apud SINGER, 2010, p. 276-7).
\end{abstract}

Em contrapartida, os romanos tinham grande consideração moral com os seus iguais. Podiam expressar generosidade e bondade, mas apenas em relação aos seus concidadãos - o 
paradigma da humanidade permanece intacto, mas a percepção do que é efetivamente "humano" é bem restrita. Escravos, criminosos e animais estavam à margem desse âmbito moral, e suas vidas não tinham valor algum. Em meio ao senso comum especista, porém, algumas vozes dissonantes se manifestaram: “Ovídio ${ }^{22}$, Sêneca ${ }^{23}$, Porfírio ${ }^{24}$ e Plutarco ${ }^{25}$, ainda sob o domínio dos espetáculos de arena romanos, são conhecidos por terem defendido os animais e também por terem se recusado a comer carne" (FELIPE, 2003, p. 42).

Segundo Sônia Felipe (2008; 2009, p. 3) os filósofos Ovídio e Sêneca defendiam os animais a partir do argumento da sensibilidade destes (assim como Pitágoras o fez), e Porfírio e Plutarco a partir da alegação de capacidade racional. Sêneca "chegou a afirmar que os animais viviam sob o auspício da sensitividade e do impulso, não tendo memória do passado, nem qualquer perspectiva acerca do futuro" (LOURENÇO, 2008, p. 81), o que reforça, de alguma forma o ser humano com status superior, e corrobora o universo hierarquizado de Aristóteles.

Já Plutarco, que escreveu uma obra chamada "Do Consumo de Carne", demonstrava uma posição muito incisiva e vanguardista (ainda hoje) sobre a dominação dos seres humanos sobre os animais: "em prol de algum bocadinho de carne privamos uma criatura inocente do sol e da luz, e daquela porção de vida e tempo que ela veio ao mundo para gozar" (PLUTARCO apud REGAN, 2009).

Porfírio é apontado como pioneiro na defesa do vegetarianismo ético. Acreditava, assim como Pitágoras, que os seres humanos não eram "onívoros-carnívoros" por natureza, e sofria pela impossibilidade de converter seus contemporâneos ao vegetarianismo, como se falasse “com barrigas que não têm ouvidos" (PORFÍRIO apud REGAN, 2009). Traduz, de maneira muito eloquente, uma de suas grandes preocupações:

Quanto a mim [...] pergunto-me por que acidente e em que estado da alma ou da mente o primeiro homem que o fez tocou o sangue com sua boca e levou os seus lábios à carne de uma criatura morta, aquele que pôs à mesa corpos mortos e fétidos e aventurouse a chamar de alimento e nutrição os pedaços que um pouco antes bramiam e gritavam, moviam-se e viviam. Como puderam seus olhos suportar o massacre de se cortarem gargantas, de se esfolar o couro, de se arrancar um membro de outro membro? Como pôde o seu nariz agüentar o fedor? Como é que a imundície não causou repulsa ao paladar daquele que fez contato com as feridas de outros e sugou fluidos e soros de ferimentos mortais? [...] É o homem que deu início a essas práticas que deveríamos buscar, não aquele que desistiu tarde demais" (PORFÍRIO apud REGAN, 2009).

\footnotetext{
22 Ovídio viveu entre 43 a.C. e 17/18 d.C. Teve decretado seu banimento de Roma, por Nero. Morreu no exílio.

23 Sêneca viveu entre 4 e 65 d.C. Acusado de conspirar contra Nero, foi condenado por esse a cometer suicídio.

24 Porfírio de Tiro viveu entre 233 e $306 / 309$ d.C.

25 Plutarco viveu entre 46 e 120 d.C.
} 
Porfírio ponderava ainda "que os animais são dotados de uma razão interna perfeita, ainda que seja externamente imperfeita, por lhes faltar a fala para poderem expressar aos demais, isto é, tornar público, o raciocínio privado" (FELIPE, 2009, p. 8). É especismo esperar que os animais exteriorizem suas sensações/emoções da mesma forma que os humanos, dado que são diferentes (mas nem por isso inferiores) pela própria natureza.

Parece que o grande trunfo de Porfírio na tentativa de derrubar o que aqui se aponta como "paradigma da humanidade" está no fato de que ele "defende que os animais não humanos merecem consideração moral devido àquilo que são (criaturas sencientes), não devido ao que não são (seres humanos aprisionados em corpos de animais)" (REGAN, 2009).

Por fim, em Porfírio (a exemplo do que afirma Plutarco), encontra-se a tese de que a crueldade contra os animais torna os humanos insensíveis também em consideração a outros humanos em condições análogas: “(A)o agir desse modo, na verdade, uma disposição assassina e uma natureza brutal se enraíza e fortalece em nós, tornando-nos insensíveis à piedade; além disso, podemos acrescentar: aqueles que pela primeira vez ousaram fazer isso, cegaram a maior parte da bondade e a tornaram ineficaz" (FELIPE, 2009, p. 11).

Em linhas gerais, como se viu, o legado deixado por esses quatro filósofos romanos tratava-se de contradiscurso no Império Romano, dado que a percepção geral “[...] acerca da natureza jurídica e do status moral dos animais representa nítida continuidade com o pensamento clássico, reproduzindo a sua estrutura básica segundo a qual eles seriam coisas, situadas no âmbito do direito de propriedade" (LOURENÇO, 2008, p. 86). Em Roma, a condição é mantida sob a pecha da impessoalidade e da coisificação, pelo que se mantém a consagração arbitrária do humano como humano pelo simples fato de ser humano.

As coisas mudaram bastante com a introdução do cristianismo e do humanismo cristão junto ao Império Romano, seu berço de nascimento. A partir desse contexto, toda a organização social se volta para uma outra forma de construção do conhecimento, embasada na fé religiosa, tema que escapa do objeto do presente investigação, por tratar-se do desenvolvimento do que ora se nomina como "paradigma da transcendência" (ou da "fé”).

Sobre o andamento histórico do ora nominado "paradigma da humanidade" como meio de consolidação do especismo, nota-se que a Idade Média (período histórico que se seguiu à ascensão e queda do Império Romano) é notadamente marcada por um "vácuo epistemológico" - o que tradicionalmente fica conhecido por "Idade das Trevas" - dada a relativa falta de produções intelectual e cultural do período. 
No tocante ao tópico aqui proposto, tal período reflete, então, uma continuidade do pensamento clássico quanto à hierarquização especista entre os seres. De acordo com textos que supostamente foram escritos por Dionísio em 532 d.C., há a afirmação de que "todas as criaturas são participações no 'bem supremo', mas cada qual se faz representar em seu grau e em seu nível hierárquico" (LOURENÇO, 2008, p. 141).

Mais tarde, filósofos como Anselmo de Cantuária (1033-1109 d.C.), Pedro Abelardo (1079-1142 d.C.), João de Salisbury (1110-1180 d.C.) e Alberto Bollstadt (1206-1280 d.C.) apresentaram a ideia de que o mundo se organizava com o escalonamento dos seres em grau de "perfectibilidade", o que poria o ser humano em degrau superior ao restante dos seres vivos (LOURENÇO, 2008, p. 144-5).

Tomás de Aquino, por sua vez, teve uma vida voltada à explicação teológica da supremacia de Deus em relação ao "homem" e do "homem" em relação ao restante da "criação" (tema do "paradigma da transcendência") bem como pensamentos em torno da questão da razão humana como superior ao instinto animal ("paradigma da razão"). Entretanto, de modo geral, mantinha a hierarquização clássica de Aristóteles, e reproduzia o paradigma da humanidade ao afirmar que o ser humano, por ser mais "perfeito" que o animal, podia utilizar-se dele inclusive para alimentação - e isso não seria errado, mas um ato de justiça. Tal como Aristóteles também o fez, defendia que os seres humanos não deviam ser cruéis com os animais apenas porque, em alguma medida, isso representaria uma violência em potencial com os humanos. Para Singer, "Nenhum argumento poderia revelar mais claramente a essência do especismo" (SINGER, 2013, p. 284).

Posteriormente, o humanismo renascentista é caracterizado pelo rompimento com a Idade Média e pelo resgate das heranças da antiguidade clássica. Isso significa que Aristóteles vai ser deixado de lado (por ter sido a grande referência filosófica medieval) "para dar lugar ao revigoramento das teorias platônicas" (LOURENÇO, 2008, p. 161), que, a seu turno, apregoavam o já referido ideal de homem-medida criado por Protágoras.

Interessante a reflexão de Peter Singer acerca de tal período histórico:

Parecia que o período da Renascença, com o surgimento do pensamento humanista em oposição à escolástica ${ }^{26}$, abalaria a visão medieval do universo e derrubaria as ideias anteriores sobre o status dos seres humanos vis-à-vis os outros animais. Mas o humanismo renascentista era, afinal, humanismo; e o significado desse termo nada tinha a ver com humanitarismo, a tendência de agir de modo humanitário. 
O Renascimento resultou na continuidade da relação especista, pois a "principal característica do humanismo renascentista é a sua insistência no valor e na dignidade dos seres humanos, bem como no lugar central ocupados por eles no universo" (SINGER, 2013, p. 2889). A fim de “disfarçar sua condição e engrandecer-se, o homem do Renascimento escolhe os animais como contra-referência (sic), como referência negativa em relação à qual tudo o que há em si recebe o brilho e o fulgor da dignidade, princípio do qual os animais são excluídos até nossos dias" (FELIPE, 2003, p. 52).

Em contrapartida, tal visão não era hegemônica, havendo algumas (poucas) vozes dissidentes em relação ao antropocentrismo-hierárquico dominante. Leonardo da Vinci (14521519), Nicolau Copérnico (1473-1543), Michel de Montaigne (1533-1595) e Giordano Bruno ${ }^{27}$ (1548-1600) são os maiores representantes da resistência ao pensamento predominante.

Leonardo da Vinci, uma das mentes mais célebres da história, adotou o vegetarianismo quando ainda era uma criança por razões éticas ${ }^{28}$. Nesse sentido: "Rei dos Animais - é como o humano descreve a si mesmo - eu te chamaria Rei das Bestas, sendo tu a maior de todas porque as ajudas só para que elas te dêem (sic) seus filhos, para o bem da tua goela, a qual transformaste num túmulo para todos os animais" (DA VINCI apud REGAN, 2004, p. 24)

Interessante é que o respeito de Da Vinci pelos animais era grande a ponto de ir além da mera abstenção à carne: “não podia suportar a visão de pássaros em cativeiro. Conta-se que, em muitas ocasiões, ele comprava pássaros, retirava-os das gaiolas e então [...] os libertava" (REGAN, 2004, p. 28).

Copérnico, por sua vez, embora jamais tenha sido qualquer coisa análoga a um defensor de direitos animais, teve grande importância no descentramento da concepção de humanidade ao (com a publicação da obra As Revoluções dos Orbes Celestes, em 1543) chamar a atenção para o fato de que a Terra não era o centro do universo (LOURENÇO, 2008, p. 18; PRADA, 2008, p. 17-8). Isso foi uma grande mudança de paradigma, dado que possibilitou ao humano repensar seu lugar no mundo como apenas “um grão de areia”, e não mais como "a espécie das espécies”. Quanto maior o espaço, menor a importância relativa de uma ou outra espécie.

\footnotetext{
26 Grosso modo, trata-se da escola de pensamento consagrada na alta Idade Média, caracterizada por conciliar a racionalidade filosófica com a doutrina religiosa. Tomás de Aquino é um de seus grandes representantes.

27 Giordano Bruno morreu na fogueira da Inquisição por não se retratar acerca de suas "heresias": "como Sêneca e Ovídio, o poder instituído condenou Bruno à morte" (FELIPE, 2003, p. 53).

28 Atribui-se a ele a famosa frase: "Eu repudio o uso da carne desde que era criança, e chegará o dia em que homens como eu julgarão o assassinato dos animais do mesmo modo como eles julgam hoje o assassinato dos homens" (DA VINCI, apud REGAN, 2004, p. 27).
} 
Acontece que o modelo copernicano - chamado heliocêntrico ${ }^{29}$ - também tinha o universo como um sistema fechado, não obstante girando em torno do Sol em vez da Terra. Apenas Giordano Bruno rompe com essa noção, que inaugura uma tese de "espaço infinito", no qual o sistema solar seria apenas um entre tantos outros, com a possibilidade de existência de um sem número de outros seres vivos. Fica visível que "ultrapassa o de Copérnico no que se refere à quebra do antropocentrismo pelo fato de que não retira somente a Terra do centro do universo, mas todo o sistema solar e mesmo a humanidade, e, assim ambos, por este motivo, deixam de ser únicos" (LOURENÇO, 2008, p. 164).

Michel de Montaigne é um dos primeiros a defender que a crueldade dos seres humanos contra os animais é um ato ruim em si mesmo - em nome dos animais, e não em função de interesses humanos. Para ele, "Presunção é nossa doença natural original", pois o homem "atribui a si mesmo qualidades divinas, e retira e separa-se da massa das demais criaturas" (SINGER, 2013, p. 290-1; FELIPE, 2003, p. 53; LOURENÇO, 2008, p. 163).

Ainda sobre o filósofo:

\begin{abstract}
Montaigne não acreditava na supremacia do homem e criticava a pretensão deste em querer julgar os animais e, embora tenha optado por uma abordagem baseada no estabelecimento das semelhanças existentes entre animais e seres humanos - como por exemplo, quando compara os gestos empreendidos pelos animais para comunicaremse entre si aos gestos empregados pelas crianças para suprir a palavra que lhes falta - justifica seu posicionamento buscando que o ser humano se recolocasse entre as demais criaturas (RAYMUNDO, 2010, p. 45).
\end{abstract}

Enquanto isso, em terrae brasilis (que não pode, pela própria natureza de seu desenvolvimento como colônia, ser enquadrado nas fases temporais de seu colonizador - o Brasil não teve Antiguidade Clássica, Idade Média ou Renascimento), saques e violações eram paulatinos e contundentes em nome de uma colonização expansionista opressora ${ }^{30}$.

Muito embora se conte sempre a história dos vencedores ${ }^{31}$, e não dos vencidos, é de conhecimento geral o genocídio cometido contra os indígenas que aqui já viviam há 50 ou 40 mil anos (DEL PRIORE; VENÂNCIO, 2010, p. 20) antes da chegada dos portugueses. O que geralmente não vem à tona, contudo, é que a situação não foi melhor para os animais que habitavam essas terras.

\footnotetext{
29 Substituiu o chamado modelo geocêntrico (ou geocentrismo) de Ptolomeu (90-168 d.C.), para quem a Terra era o centro de um universo finito e fechado - o que, de acordo com Irvênia Prada, já tinha sido previsto por Aristóteles, séculos antes (PRADA, 2007, p. 16).

30 No entanto, os colonizadores se sentiram muito legítimos em tomar conta de um território cheio de "gentes sem fé, sem lei, sem rei" (CLASTRES, 2013, p. 33). Por isso, os indígenas eram parecidos com animais (o que, ante uma percepção especista - mais do que racista permitia e eles fazerem o que bem julgassem em detrimento dessa população).

31 "No ar, o som de araras, maritacas, tuins e pica-paus; era “a terra dos papagaios", terra ruidosa que, em cor de incontáveis 'prumagens', irá figurar em vários mapas. [...] O Brasil havia sido “oficialmente descoberto"” (DEL PRIORE; VENÂNCIO, 2010, p. 18).
} 
Os portugueses tinham como produto principal da exploração o famoso pau-brasil, mas também se assenhoravam incisivamente de escravos e papagaios, como se fossem coisas. Não bastasse isso, havia ainda contrabando de recursos naturais e animais silvestres: "[...] a embarcação francesa Peregrina (Pélèrine) [...] foi capturada pelos portugueses no Mediterrâneo por uma esquadra da Corte com quinze mil toras de pau-brasil, 3 mil peles de leopardo, seiscentos papagaios, trezentos bugios e saguis" (EZEQUIEL, 2014, p. 22). A colonização não só do Brasil, mas da América Latina inteira - representou um tratamento tão ou mais desrespeitoso do que já se via na Europa em relação aos animais.

Volta-se ao contexto europeu. A linha divisória entre seres humanos e animais como legitimadora da exploração permanecia claramente colocada, inclusive como meio de enquadrar humanos em uma animalidade que possibilitasse sua exclusão do seleto grupo privilegiado de membros da "sociedade" humana. A escravidão é o maior exemplo disso, pois tem como premissa a "animalização" e "desumanização" das pessoas que seriam feitas escravas.

O contex to dos séculos XVI e XVII revelam grandes transformações, com o surgimento do Humanismo Renascentista, da Revolução Científica, da Reforma Protestante e do Contratualismo - esses três últimos movimentos históricos serão estudados oportunamente, com os adventos dos paradigmas da transcendência e da razão.

Pode-se dizer, contudo, que o paradigma da humanidade volta ao enfoque - felizmente sob uma perspectiva crítica - no século XVIII, com a importante obra de Humphry Primatt (1735-1777/6) chamada "Uma Dissertação sobre o Dever de Compaixão e o Pecado da Crueldade contra os Animais Brutos" ${ }^{\prime 2}$. Nela, Primatt aponta a moral posta como antropocêntrica e discriminatória em relação aos animais - o que contemporaneamente restou absorvido por Peter Singer, Tom Regan e Richard D. Ryder (FELIPE, 2006, p. 206). Mostrase como um grande crítico dessa conduta discriminatória - hoje conhecida por especismo:

\footnotetext{
Desviados por esse preconceito, construído a nosso favor, ignoramos alguns animais como se fossem meras excrescências da natureza, aquém de nossa atenção, e infinitamente não dignos de cuidado e reconhecimento divinos; outros, consideramos como se feitos apenas para nos prestar serviços; e, por poder usá-los, somos indiferentes e descuidados com relação à sua felicidade ou miséria, e com muita dificuldade nos permitimos supor que exista qualquer dever que nos obrigue em relação a eles (PRIMATT apud FELIPE, 2006, p. 212).
}

\footnotetext{
32 No original: “A Dissertation on the Duty of Mercy and Sin of Cruelty to Brute Animals".
} 
Fica clara sua discordância em relação ao tratamento que o ser humano dispensa aos animais. No entanto, entende-se que, em que pese haja uma crítica ao paradigma da humanidade como forma de perpetuação do especismo, tal autor não o supera, pois mantém o animal vinculado a um ser humano que tem a obrigação de ser bondoso. Por mais avançado que fosse o pensamento desse brilhante filósofo, pecou em manter o ser humano como protagonista de uma relação que depende de sua "benevolência". Para superar o paradigma da humanidade, necessário retirar do humano o status de espécie suprema, o que não se verifica nessa teoria.

É, contudo, notória a influência benéfica de Primatt como embasamento teóricofilosófico para os direitos animais e, embora não chegasse a proclamar direitos em espécie aos animais, serviu de base teórica ao filósofo que posteriormente o fez, Henry Salt (1851-1939).

Antes de Salt, entretanto, a humanidade, enquanto valor supremo, sofre outro grande descentramento - depois de Copérnico - com a teoria da evolução das espécies do britânico Charles Darwin (1809-1892). Essa interpretação do "humano excelso", com valor supremo, é fortemente rebatida por ele, que em suas anotações particulares assim escrevera: "O homem, em sua arrogância, acredita ser uma grande obra, merecedora da intermediação de uma divindade. É mais humilde, penso eu, mais verdadeiro considerar que foi criado a partir dos animais" (DARWIN apud SINGER, 2013, p. 298).

Posteriormente, em “A Origem das Espécies", Darwin aponta que humanos e animais decorrem de um único processo evolutivo, e que as diferenças entre uns e outros são apenas de grau e não de categoria. Carlos Naconecy, nessa toada, aponta:

Desde Darwin sabemos que todos somos animais. Só aqueles que desconhecem o legado darwinista pensam que animais e humanos pertencem a mundos separados. Alguns ainda pensam que os macacos estão mais próximos dos sapos que dos seres humanos. Essas pessoas consideram que somos criaturas "sobrenaturais", já que só nós pensamos. Mas Darwin nos ensinou que as habilidades entre os animais (humanos e não-humanos) não são uma questão de tudo ou nada, mas, sim, de grau, de continuum. E se levarmos à sério a contribuição darwiniana, teremos que revisar nossa opinião sobre o tratamento que damos aos animais. A implicação ética do darwinismo seria a de que um parentesco biológico carrega um parentesco moral, em face do compartilhamento de habilidades (cognitivas, emocionais, sociais, etc.) derivado da identidade genética comum entre humanos e não-humanos (NACONECY, 2006, p. 143).

Em “A Expressão dos Emoções no Homem e nos Animais", Darwin estudou a exteriorização de todas as emoções dos animais, igualando-os à medida que tratava da mesma maneira exemplificativa uns e outros. Embora eventualmente apontasse o humano em situações 
específicas e peculiares, percebe-se que "o estudo da teoria das expressões confirma até certo ponto a conclusão de que o homem descende de alguma forma animal anterior, e reforça a crença na unidade específica ou subespecífica das inúmeras raças” (DARWIN, 2000, p. 341).

O grande paradoxo no que se refere ao legado darwinista está no fato de que, como bem aponta Marcia Raymundo, considerando as semelhanças biológicas entre todas as espécies, "a teoria de Darwin possibilitou a extrapolação dos dados obtidos em pesquisas com animais para seres humanos, dando um maior respaldo aos cientistas que utilizavam animais em suas pesquisas", ainda que não propositalmente. Nesse sentido, a autora acrescenta: "Ou seja, justamente por apresentarem semelhanças com os seres humanos é que os animais são utilizados [...] em benefício do homem” (RAYMUNDO, 2010, p. 47). E, não obstante o argumento contemporâneo de que os animais não servem adequadamente como modelos substitutivos de humanos - pela diferenciação fisiológica inerente a cada uma das espécies - permanecem sendo explorados para esse fim.

Além disso, a teoria evolucionista de Darwin - ao provar que o lugar do ser humano no mundo não é privilegiado - foi interpretada de maneira deturpada a fim de "justificar a colocação do homem como entidade superior às demais, na medida em que o mecanismo da 'sobrevivência do mais aptos' conduziria o homem a ocupar o lugar de destaque" (LOURENÇO, 2008, p. 278). De certa forma, e resguardadas as proporções, aconteceu com Darwin o que posteriormente viria a acontecer com Einstein e sua Teoria da Relatividade (usada como base para fazer a bomba atômica): embora cunhada com a intenção de produzir boa ciência, seu uso prejudicial posterior quase põe a perder todo o valor do que fora descoberto, prejudicando a própria essência da teoria.

Henry Salt, filósofo britânico que viveu entre a segunda metade do século XIX e a quase totalidade das primeiras quatro décadas do século XX (1851-1939), lança a obra "Animal Rights", que, segundo Sônia Felipe, é a primeira sobre "direitos" para os animais na história da filosofia europeia. Salt apresenta em 1892 temas que ainda hoje são considerados de vanguarda ${ }^{33}$, inclusive no que se refere à necessidade de vinculação entre as causas de direitos animais e direitos humanos - e que ainda parece longe de se ver efetivada. Segundo ele: “A emancipação humana da crueldade e da injustiça trará consigo, no devido tempo, a emancipação também dos animais. As duas reformas estão inseparavelmente vinculadas, e nenhum pode ser plenamente realizada sem a outra". É interessante perceber que tal concepção não se assemelha em nada àquele pensamento aristotélico que defende o animal apenas enquanto "propriedade" ou "interesse" humano: Salt via no animal um fim em si mesmo e defendia arduamente a 
concepção de direitos, mas aproveitava a problemática análoga de direitos humanos (ainda também não efetivados) para conciliá-las - com o que se concorda ${ }^{34}$.

Para além das importantes referências tradicionais (filosóficas) na construção do pensamento animalista, dentro da abordagem do paradigma da humanidade, mostra-se de suma importância trazer à tona o que a literatura produziu de mais importante nesse sentido, primeiro sob a perspectiva aparentemente favorável ao paradigma da humanidade - pelos romances "Memórias Póstumas de Brás Cubas" (1881) e "Quincas Borba" (1891), ambas de Machado de Assis (1839-1908) -, e posteriormente pela perspectiva crítica - apontada no conto "Relato para Academia” de Franz Kafka (1883-1924).

Em "Memórias Póstumas de Brás Cubas", Machado de Assis começa a construir a tese filosófica que posteriormente terminaria de desenvolver em "Quincas Borba": o humanitismo, que consiste em um sistema filosófico pautado na busca pela felicidade humana, e que tem no humano não apenas a centralidade, mas o único valor. Segundo o filósofo Quincas Borba, tratase, então, de "[...] um novo sistema de filosofia, que não só explica e descreve a origem e a consumação das coisas, como faz dar um grande passo adiante de Zenon e Sêneca, cujo estoicismo era um verdadeiro brinco de crianças ao pé da minha receita moral” (ASSIS, 1999, p. 167). E continua: "É singularmente espantoso esse meu sistema; retifica o espírito humano, suprime a dor, assegura a felicidade, e enche de imensa glória o nosso país. Chamo-lhe Humanitismo, de Humanitas, princípio das coisas" (ASSIS, 1999, p. 167).

O paradigma da humanidade fica claro no trecho que segue: "Nota que eu não faço do homem um simples veículo de Humanitas; não, ele é ao mesmo tempo veículo, cocheiro e passageiro; ele é o próprio Humanitas reduzido; daí a necessidade de adorar-se a si próprio" (ASSIS, 1999, p. 196). Nessa concepção, não há qualquer discriminação aos animais porque eles são simplesmente desconsiderados e silenciados. O "homem" é a única "medida de todas as coisas".

\footnotetext{
33 Em uma passagem dessa publicação - publicada no volume 6 da Revista Brasileira de Direito Animal em 2010 -, Salt discute a ainda persistente polêmica entre "benestaristas" e "abolicionistas", tema contemporâneo que se resume no embate entre a necessidade de reformas paulatinas (benestaristas) ou abolição efetiva da exploração animal (o que ainda causa muita celeuma no movimento de proteção animal). Sobre isso, apresentou interessante perspectiva: [...] como as mudanças normalmente não vêm de uma só vez, mas parceladamente, o reformador prático deve fixar os olhos não apenas em um horizonte, mas em dois; e ao mesmo tempo em que se protege contra o erro de sacrificar a meta distante pela mais próxima, deve igualmente estar atento à perda da meta mais próxima pela ansiedade em chegar a uma meta mais distante. Em uma palavra, não há necessidade de restrição ou abolição, mas de restrição e abolição; pois a primeira não deve ser uma alternativa, mas a introdução e porta de entrada, digamos, para a última (SALT, 2006, p. 34). E, efetivando seu posicionamento entre as duas correntes de pensamento, acrescenta: “A mente mais arguta é aquela que pode olhar tanto para o presente quanto para o futuro, para o real e o ideal”. Apontava para a necessidade de a causa animal não se perder entre condutas chauvinistas.

34 Como já apontava Porfírio, o animal deve ser respeitado por sua própria essência, e não como mera condição do respeito entre seres humanos. De acordo com Carlos Naconecy: "Se temos o dever de evitar a opressão, exploração e escravidão dos animais, isso decorre do fato que atitudes tirânicas, exploradoras e destrutivas são erradas em si mesmas - e não apenas porque isso tem um benefício utilitário para a vida humana" (NACONECY, 2006, p. 167).
} 
Em contrapartida, Quincas Borba via no seu cachorro uma quase pessoa, a ponto de atribuir-lhe seu próprio nome, pois, para ele "Humanitas [...] é o princípio da vida e reside em toda a parte, existe também no cão, e este pode assim receber um nome de gente, seja cristão ou muçulmano" (ASSIS, 1994, p. 4). Ocorre que, de modo geral, a tese filosófica que construiu é especista e simplesmente ignora a existência de valor na vida animal, além de desconsiderar a animalidade do próprio "homem" e colocá-lo como valor supremo do universo ${ }^{35}$ - a ponto de ser o próprio objeto de adoração.

Machado de Assis nunca se propôs a pensar a questão animal, o que, entretanto, não necessariamente é passível de crítica, dado que não era filósofo ou jurista, mas escritor. De certa forma, porém, tal teoria trazida à baila em sua ficção pode servir de boa crítica ao paradigma da humanidade, se considerado o fato de que Machado de Assis põe Quincas Borba em uma posição que beira ao ridículo, por sua empáfia e arrogância no modo como colocava tais ideias, e também porque posteriormente aparece para seu amigo Brás Cubas em situação de notável loucura $^{36}$. Assim, mesmo não sendo um "pós-antropocêntrico", o autor é consciente dos exageros e erros dessa teoria.

O engraçado, e, ao mesmo tempo, desolador, é que a teoria humanista sarcástica que Machado de Assis apresentada pela “voz” de Quincas Borba já teve acolhida sob outras formas ao longo dos séculos, e por pessoas reais que se tinham como pensadoras.

A literatura de Franz Kafka ajudou mais diretamente na crítica à diferenciação imposta entre humanos e animais. O conto "Um Relatório para a Academia"37 é apenas um entre vários textos dos quais o escritor fala, ainda que não diretamente, sobre a condição animal ou sobre a animalidade do homem ${ }^{38}$, mas parece ser o maior crítico ao paradigma da humanidade ora estudado. Pedro Vermelho ${ }^{39}$, narrador do conto, é um macaco que virou homem por amestramento. Depois de capturado em uma caçada, ele mesmo quis esse destino, muito embora consciente de que não fosse livre para isso: ou virava homem, ou ficaria preso em um zoológico para o resto de sua vida - e ter que escolher entre uma coisa e outra não é liberdade ${ }^{40}$. Ao longo

\footnotetext{
35 Sobre a centralidade do homem no universo, Quincas Borba comenta: “a Terra, inventada unicamente para seu recreio [...], como as estrelas, as brisas, as tâmaras e o ruibarbo" (ASSIS, 1999, p. 198).

36 "Vinha demente. Contou-me que, para o fim de aperfeiçoar o Humanitismo, queimara o manuscrito todo e ia recomeçá-lo. A parte dogmática ficava completa, embora não escrita; era a verdadeira religião do futuro. [...] A voz mal podia sair-me do peito; e aliás não tinha descoberto toda a cruel verdade. Quincas Borba não só estava louco, mas sabia que estava louco, e esse resto de consciência, como uma frouxa lamparina no meio das trevas, complicava muito o horror da situação [...]; chegou até a reproduzir uma dança sacra que inventara para as cerimônias do Humanitismo. A graça lúgubre com que ele levantava e sacudia as pernas era singularmente fantástica. Outras vezes amuava-se a um canto, com os olhos fitos no ar, uns olhos em que, de longe em longe, fulgurava um raio persistente da razão, triste como uma lágrima” (ASSIS, 1999, p. 139).

37 Publicado junto à obra "Um Médico Rural", originalmente no ano de 1917.

38 O que pode ser observado também nos contos "O Novo Advogado", a "Toca" e "Investigações de um Cão", e até, de certa forma, no famoso romance

"A Metamorfose".

39 Ou Pedro Rubro, de acordo com algumas traduções para o português.

40 “[...] não me atraía imitar os homens: eu imitava porque procurava uma saída, por nenhum outro motivo” (KAFKA, 1999, p. 70).
} 
de tal texto, não obstante seu caráter quase surreal - como é típico de Kafka -, há uma constatação geral de que os hominídeos e símios não se diferenciam em muita coisa, não se justificando a diferença entre uns e outros. A passagem mais contundente nesse sentido traz Pedro Vermelho referindo-se aos membros da Academia (a quem ele dirige seu relatório acerca de sua pregressa vida de macaco). Diz o seguinte:

[...] falando francamente, sua origem de macaco, meus senhores, até onde tenham atrás de si algo dessa natureza, não pode estar tão distante dos senhores como a minha está distante da minha. Mas ela faz cócegas no calcanhar de qualquer um que caminhe sobre a terra - do pequeno chimpanzé ao grande Aquiles (KAFKA, 1999, p. 60).

E Kafka toca no "calcanhar de Aquiles" da humanidade ao apontar sua origem animal, como poucos cientistas (filósofos ou não) o fizeram. Vislumbra-se que o conceito de humanidade não é nada se não um engodo para tentar ludibriar aquilo que Darwin veio a descobrir: que os humanos não foram tão longe assim na escala evolutiva, e que as pequenas diferenças não fazem seres semidivinos ou tampouco superiores.

Apesar disso, de acordo com Daniel Lourenço, ao longo do tempo construiu-se artificialmente

[...] a idéia (sic) de que a categoria "humano" é a única fundante e coincidente com a noção de "direito". Entretanto, [...] esse processo de auto-identificação do direito com o ser humano é também uma triste história de exclusão de tudo aquilo que não se enquadre nessa categoria de "humanidade" (LOURENÇO, 2008, p. 27-8).

Essa compreensão - que identifica diretamente as categorias "humano", "pessoa" e "sujeito de direito" - se dá por mera arbitrariedade, não pode persistir e vem sendo combatida por autores contemporâneos de várias áreas do conhecimento - conforme será apontado no Capítulo 3. Por ora, restou apontado o que houve de embrionário na construção e desconstrução do paradigma da humanidade enquanto base para o especismo.

\section{CONSIDERAÇÕES FINAIS}

Restaram demonstrados alguns dos mais relevantes traços históricos da construção do que se pode chamar de "não-direitos animais". Observou-se que a eleição dos sujeitos de 
direitos se deu por uma arbitrária construção pautada numa selecionada "humanidade" como critério de exclusão de tudo aquilo que não se enquadrasse nessa seleta classificação.

Ocorre que hoje ainda essa questão permanece pendente de resolução, com pífios avanços na esfera menos efetiva de direitos, que é a penal - representado pela criminalização de algumas condutas pontuais tidas como "crueldade". Fato é que os animais permanecem sendo mortos aos bilhões para satisfazer os mais diversos interesses humanos (especialmente alimentícios).

O ser humano continua entendendo-se como ser excelso, superior a todos os demais seres, o que lhe confere a competência para decidir quem vive, quem morre, quem tem direitos e quem não tem. As expressões "humano", "humanidade" ou "humanismo" em nada se confundem com a expressão "humanitarismo" ou "humanitário".

Partindo, então, daquilo que deveria significar ser "humanitário", "humanitarista" ou "humanista", surgem inquietudes no seguinte sentido: se o humano é tão especial em relação às demais espécies - a ponto de tornar-se paradigma -, por que essa valoração não pôde significar algo belo e valoroso em vez de um amontoado de egoísmo, desespero e sofrimento? Por qual razão não se construiu igualdade e cuidado no lugar de subalternização e exploração?

Sendo a única espécie dita racional, o ser humano poderia ter criado as condições para uma "racionalização ética", que possibilitasse à espécie condições para um desenvolvimento sustentável (em relação à recursos naturais e econômicos) pautado na fraternidade. A estética poderia ter sido um valor a ser perseguido em detrimento do acúmulo de riquezas: valorizar-seia mais fazer versos do que ter escravos; pintar telas ou paredes em vez de promover touradas; tocar harpa no lugar de assassinar inocentes (humanos ou animais); alimentar-se de frutos vivos da terra, e não de partes putrefantes do corpo de outros seres.

Fato é que a concepção de "humanidade" ficou atrelada a outros valores, bem diversos do que ora se propôs: "humano" passou a significar, desde o início da História, superioridade expropriatória, exploração dos mais fracos, luta por acúmulo de riquezas; e "humanismo", a consagração da forma de vida desse humano autocentrado e mesquinho. Por consequência, a organização dos sistemas jurídico, econômico e social se pautaram nessa forma de ver o mundo, o que resultou em exclusão de todos aqueles que não conseguiram se impor como "humanos" dentro dessa lógica.

Juridicamente, tais reflexões são necessárias à medida que possibilitam a reabertura da composição da categoria "sujeitos de direitos". Questionar o paradigma da humanidade enquanto categoria histórico-filosófica é possibilitar a reconstrução dos institutos jurídicos, 
dado que o direito só se modifica com a evolução das ciências que lhe são intrinsicamente correlatas.

Por fim, tem-se como alcançado o principal objetivo do presente estudo, que era abordar o "paradigma da humanidade" como um dos mais relevantes fundamentos do especismo e da perpetuação da hierarquia entre humanos e animais. Quem sabe se possa, a partir dessas considerações, pensar modos de desconstrução desse ideal especista que marca desde sempre a história da humanidade a fim de, no futuro, construir uma sociedade liberta da escravização de seres inocentes.

\section{REFERÊNCIAS}

ASSIS, Machado de. Memórias Póstumas de Brás Cubas. Porto Alegre: L\&PM, 1999. ASSIS, Machado de. O Alienista. In: 50 Contos de Machado de Assis. São Paulo:

Companhia das Letras, 2007. p. 38-81.

ASSIS, Machado de. Quincas Borba. Rio de Janeiro: Editora Nova Aguilar, 1994. Disponível em: <http://machado.mec.gov.br>. Acesso em: 17 jul. 2015.

CHAUÍ, Marilena. Convite à Filosofia. São Paulo: Editora Ática, 2001. CLASTRES, Pierre. A Sociedade Contra o Estado. São Paulo: Cosac Naify, 2013. COETZEE, John Maxwell. A Vida dos Animais. 2. ed. São Paulo: Companhia das Letras,

2002.

DARWIN, Charles. A Origem das Emoções no Homem e nos Animais. São Paulo: Companhia das Letras, 2000.

DEL PRIORE, Mary; VENÂNCIO, Renato. Uma Breve História do Brasil. São Paulo: Editora Planeta do Brasil, 2010.

DEMÓCRITO. Fragmentos. Pré-Socráticos: Coleção Os Pensadores. São Paulo: Nova Cultural, 2005. p. 259-302.

DIAS, Edna Cardozo. A Tutela Jurídica dos Animais. Belo Horizonte: Mandamentos, 2000.

DIAS, Paula Barata. Em Defesa do Vegetarianismo: O Lugar de Porfírio de Tiro na Fundamentação Ética da Abstinência da Carne dos Animais. In: ___ _ SOARES, Carmen (Coords.). Contributos para a História da Alimentação na Antiguidade. Coimbra: Imprensa da Universidade de Coimbra, 201?. Disponível em: <https://digitalis-dsp.uc.pt/bitstream/ 10316.2/29986/6/7-Contributos\%20para\%20a\%20hist\%C3\%B3ria\%20da\%20alimenta\%C3\% A7\%C3\%A3o\%20na\%20antiguidade.pdf?ln=eng>. Acesso em: 23 jul. 2015.

DUSSEL, Enrique. Ética da Libertação: Na Idade da Globalização e da Exclusão. 4. ed. Petrópolis: Vozes, 2012. 
EZEQUIEL, Márcio. Receita Federal: História da Administração Tributária no Brasil. Brasília: Receita Federal do Brasil, 2014.

FELIPE, Sônia T. Antropocentrismo, Sencientismo e Biocentrismo: Perspectivas Éticas Abolicionistas, Bem-estaristas e Conservadoras e o Estatuto de Animais Não-humanos. Revista Páginas de Filosofia, São Paulo, v. 1, n. 1, p. 1-30, jan.-jul., 2009. Disponível em: <https://www.metodista.br/revistas/revistas-ims/index.php/PF/article/viewFile/864/1168>. Acesso em: 19 jul. 2015.

FELIPE, Sônia T. Fundamentação Ética dos Direitos Animais. Revista Pensata Animal, v. 1, n. 11, mai., 2008. Disponível em: <http://pensataanimal.net/arquivos-da-pensata/38soniatfelipe/200-fundamentacao-etica $>$. Acesso em: 25 jul. 2015.

FELIPE, Sônia T. Por uma Questão de Princípios: Alcance e Limites da Ética de Peter Singer em Defesa dos Animais. Florianópolis: Fundação Boiteux, 2003.

FELIPE, Sônia T. Somatofobia: Violência Contra Animais Humanos e Não-humanos; As Vozes Dissidentes na Ética Antiga. Revista Pensata Animal, v. 1, n. 2, jun., 2007. Disponível em: <http://www.pensataanimal.net/arquivos-da-pensata/38-soniatfelipe/118-somatofobiai>. Acesso em: 24 jul. 2015.

FERRY, Luc. A Nova Ordem Ecológica: a Árvore, o Animal, o Homem. Rio de Janeiro: DIFEL, 2009.

GORDILHO, Heron José de Santana. Abolicionismo Animal. Salvador: Evolução, 2008. GRANDES FILÓSOFOS: Coleção Os Pensadores. São Paulo: Nova Cultural, 2005. JUNGES, José Roque. Ética Ambiental. São Leopoldo: Editora Unisino, 2004.

KAFKA, Franz. Um Médico Rural. São Paulo: Companhia das Letras, 1999.

LEVAI, Laerte Fernando; DARÓ, Vânia Rall. Experimentação Animal: Histórico, Implicações Éticas e Caracterização como Crime Ambiental. In: TRÉZ, Thales (Org.). Instrumento Animal: O Uso Prejudicial de Animais no Ensino Superior. Bauru: Canal 6, 2008.

LOURENÇO, Daniel Braga. Direito dos Animais: Fundamentação e Novas Perspectivas. Porto Alegre: Sergio Antonio Fabris Ed., 2008.

LOVELOCK, James. A Vingança de Gaia. Rio de Janeiro: Intrínseca, 2006.

MORIN, Edgar; KERN, Anne Brigitte. Terra-pátria. 4. ed. Porto Alegre: Sulina, 2003.

NACONECY, Carlos. Ética \& Animais: Um Guia de Argumentação Filosófica. Porto alegre: EDIPUCRS, 2006.

OST, François. Natureza à Margem da Lei: A Ecologia à Prova do Direito. Lisboa: Instituto Piaget, 1995. 
PAZZINI, Bianca. Por uma Igual Dignidade dos Diferentes: Efetivação dos Direitos dos Animais e Superação do Especismo a Partir da Ética da Libertação de Enrique Dussel. In: Filosofia da Libertação: Historicidade e Sentidos da Libertação Hoje [E-book]. Anais. Nova Petrópolis: Nova Harmonia, 2014. Disponível em: <http://www.ufrgs.br/cbfil/files/2014/09/ Anais-Filosofia-da-liberta\%C3\%A7\%C3\%A3o-3.pdf>. Acesso em: 24 jul. 2015.

PRADA, Irvênia Luiza de Santis. Os Animais são Seres Sencientes. In: TRÉZ, Thales (Org.). Instrumento Animal: O Uso Prejudicial de Animais no Ensino Superior. Bauru: Canal 6, 2008.

PRÉ-SOCRÁTICOS: Coleção Os Pensadores. São Paulo: Nova Cultural, 2005. RAYMUNDO, Marcia Mocellin. História da Ética Animal. In: FEIJÓ, Anamaria Gonçalves dos Santos; BRAGA, Luisa Maria Gomes de Macedo; PITREZ, Paulo Márcio Condessa (Orgs.). Animais na Pesquisa e no Ensino: Aspectos Éticos e Técnicos. Porto Alegre: EDIPUCRS, 2010.

REGAN, Tom. Jaulas Vazias: Encarando o Desafio dos Direitos dos Animais. Porto Alegre: Lugano, 2006.

REGAN, Tom. Vozes Vegetarianas. Revista Pensata Animal, v. 1, n. 21, mar., 2009. Disponível em: $\quad<$ http://www.pensataanimal.net/arquivos-da-pensata/58-tomregan/251-vozesvegetarianas-um-comentario >. Acesso em: 25 jul. 2015.

SALT, Henry. Benestaristas e Abolicionistas. Revista Brasileira de Direito Animal, Salvador, ano 5, v. 6, p. 33-6, jan.-jun. 2010. Disponível em: <http://www.portalseer.ufba.br/ index.php/RBDA/article/viewFile/11070/7985>. Acesso em: 01 ago. 2015.

SINGER, Peter. Libertação Animal. São Paulo: Editora WMF Martins Fontes, 2013.

SILVA, Tagore Trajano de Almeida Silva. Direito Animal e Pós-humanismo: Formação e Autonomia de um Saber Pós-humanista. Revista Brasileira de Direito Animal, Salvador, v. 8, n. 14, p. 161-259, 2013a. Disponível em: <http://www.portalseer.ufba.br/index.php/RBDA/ article/viewFile/9144/6591>. Acesso em: 16 jul. 2015.

SILVA, Tagore Trajano de Almeida Silva. O Ensino do Direito Animal: Um Panorama Global. Revista de Direito Brasileira, Florianópolis, ano 3, v. 6, set.-dez., 2013, p. 232-272, 2013b.

SILVA, Tagore Trajano de Almeida Silva. Direito Animal \& Ensino Jurídico: Formação e Autonomia de um Saber Pós-humanista. Salvador: Evolução, 2014. SÓFOCLES. Antígona. Porto Alegre: L\&PM, 2013.

ZAFFARONI, Eugenio Raul. La Pachamama y El Humano. Buenos Aires: Ediciones Madres de Plaza de Mayo, 2013.

WISE, Steven. Rattling the Cage. Cambridge: Perseus Books, 2000. 